\title{
Mount Rainier-Living Safely With a Volcano in Your Backyard
}

ajestic Mount Rainier
soars almost 3 miles
(14,410 feet) above sea level
and looms over the expanding
suburbs of Seattle and Tacoma,
Washington. Each year almost
two million visitors come to
Mount Rainier National Park
to admire the volcano and its
glaciers, alpine meadows, and
forested ridges. However, the
volcano's beauty is deceptive-
U.S. Geological Survey (USGS)
research shows that Mount
Rainier is one of our Nation's
most dangerous volcanoes. It
has been the source of countless
eruptions and volcanic mudflows
(lahars) that have surged down
valleys on its flanks and buried
broad areas now densely
populated. To help people live
more safely with the volcano,
USGS scientists are working
closely with local communities,
emergency managers, and the
National Park Service.

Mount Rainier, an active volcano currently at rest between eruptions, is the highest peak in the Cascade Range. Its edifice, capped by snow and 25 glaciers, has been built up by untold eruptions over the past 500,000 years. It last erupted in 1894-95, when small summit explosions were reported by observers in Seattle and Tacoma. Mount Rainier's next eruption might be of similar or larger size and could produce volcanic ash, lava flows, and avalanches of intensely hot rock and volcanic gases, called "pyroclastic flows." Some of these events swiftly melt snow and ice and could produce torrents of meltwater that pick up loose rock and become rapidly flowing slurries of mud and boulders known as "lahars." In contrast to lava flows and pyroclastic flows that are unlikely to extend farther

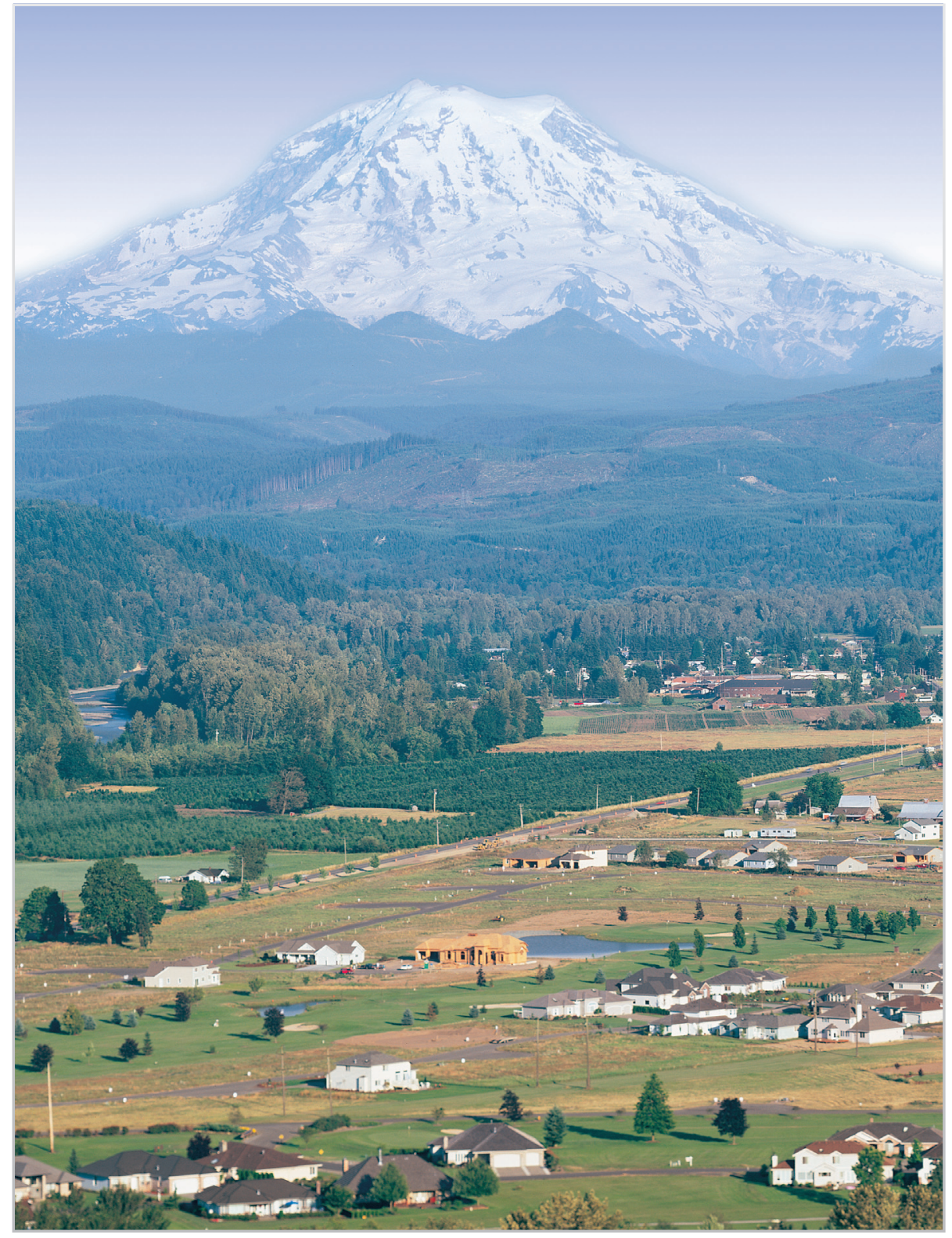

The flat floor of the Puyallup River valley near Orting, Washington, is formed by deposits of the 500-year-old Electron lahar, which surged down from Mount Rainier (in background). Lahars, or volcanic mudflows, are rapidly flowing slurries of mud and boulders that destroy or bury most manmade structures in their paths. Lahars from Mount Rainier can travel for tens of miles along river valleys and reach Puget Sound. (USGS photograph by D.E. Wieprecht.)

than 10 miles from the volcano's summit and remain within Mount Rainier National Park, the largest lahars can travel for tens of miles and reach Puget Sound. Volcanic ash will be distributed downwind, most often toward the east, away from Puget Sound's large population centers. Airborne plumes of volcanic ash can greatly endanger aircraft in flight and seriously disrupt aviation operations. Although seldom life threatening, volcanic ash fallout on the ground can be a nuisance to residents, affect utility and transportation systems, and entail substantial clean-up costs. 




\section{Lahars Pose the Greatest Risk}

At Mount Rainier, the risk from lahars is greater than from lava flows, volcanic ash fall, or other volcanic phenomena because some pathways for future lahars are densely populated and contain important infrastructure such as highways, bridges, ports, and pipelines. Lahars look and behave like flowing concrete, and they destroy or bury most manmade structures in their paths. Past lahars probably traveled 45 to 50 miles per hour and were as much as 100 feet or more thick where confined in valleys near the volcano. They thinned and spread out in the wide valleys downstream, slowing to 15 to 25 miles per hour. Deposits of past lahars are found in all of the valleys that start on Mount Rainier's flanks.

\section{How Hazardous is Mount Rainier?}

Mount Rainier has erupted less often and less explosively in recent millennia than its well-known neighbor, Mount St. Helens. However, the proximity of large population centers in valleys susceptible to lahars from Mount Rainier makes it a far greater threat to life and property than Mount St. Helens for the following reasons:

\section{- Population and development at} risk-About 80,000 people and their homes are at risk in Mount Rainier's lahar-hazard zones. Key infrastructure such as major highways and utilities cross through these zones, which also contain economically important businesses, hydroelectric dams, and major seaports.

- Size and frequency of laharsDuring the past several thousand years large lahars have reached the Puget Sound lowland on average at least once every 500 to 1,000 years. Smaller flows not extending as far as the lowland occurred more frequently. If future large lahars happen at rates similar to those of the past, there is roughly a 1-in-10 chance of a lahar reaching the Puget Sound lowland during an average human lifespan.

- There may be little or no advance warning-Studies by U.S. Geological Survey (USGS) scientists show that at least one of Mount Rainier's recent large landslide-generated lahars may have occurred when the volcano was quiet and not providing the warning signs typical of a restless and erupting volcano. In such a rare case, the only warning could be a report that a lahar is already underway.

\section{Two Types of Lahars}

Mount Rainier can generate two types of lahars that can threaten surrounding valleys:

- Meltwater-generated lahars-Mount Rainier supports more than one cubic mile of glacial ice-as much as all other Cascade Range volcanoes combined. During past eruptive episodes, swift melting of snow and ice by pyroclastic flows and other events caused numerous lahars. Such lahars would be preceded by events that warn of an impending eruption.

- Landslide-generated lahars-Landslides can be triggered when molten rock (magma) intrudes into a volcano and destabilizes it, as happened at Mount St. Helens in 1980, or they may be triggered by large earthquakes. They may also be the result of the eventual failure of rocks that were weakened by the action of acidic fluids. Magma releases gases and heat creating hot, acidic ground water that, over time, can convert hard volcanic rock into weak, clay-rich rock by a process called hydrothermal alteration. When masses of water-saturated clay-rich rock slide away, they transform rapidly into a lahar. Although most large landslides at Mount Rainier occurred during eruptive periods and were probably triggered by magma intrusion or by explosive eruptions rocking the volcano, the origin of at least one, the 500-year-old Electron lahar, may not be related to eruptions. This lahar left deposits as much as 20 feet thick, and buried an old-growth forest in the vicinity of modern-day Orting.

\section{Are All Parts of the Volcano Susceptible to Landslides?}

The west flank of Mount Rainier, including the head of the Puyallup River, has the greatest potential for unleashing large landslides that become far-traveled lahars, because it has the largest amount of weakened clay-rich rock at high altitude. Therefore, the Puyallup River valley and, to a lesser extent, the Nisqually River valley, whose basin includes some of the weakened rock, are at most risk from such events. Little Tahoma Peak on the east side of the volcano and many other cliffs and steep slopes can fail in landslides, such as one in December 1963 that traveled several miles, but such events are too small to generate lahars. In contrast to landslides, lahars generated by eruptions could descend any of the valleys originating on Mount Rainier.

\section{Long-Term Effects of Lahars}

Lahars fill stream channels and bury valley floors with deposits of boulders, sand, and mud a few feet to tens of feet thick. These deposits readily erode as rivers and streams reestablish their channels, shedding abundant sediment downstream over years to decades.

Because of this, downstream valley floors initially unaffected by a lahar may later suffer increased flooding and progressive burial by remobilized sediment. Recent studies have revealed extensive layers of sandy sediment from Mount Rainier that extend to the Port of Seattle along the Green and Duwamish River valleys. This sediment was rapidly eroded from the deposits of lahars caused by eruptions about 1,000 years ago, even though the lahars themselves did not extend much past present-day Auburn, which lies about 20 miles south of downtown Seattle.

\section{Debris Flows Threaten Areas in Mount Rainier National Park}

Almost annually, water released from glaciers or runoff from intense rainfall incorporates rocks and sediment to form "debris flows" that affect valleys 


\section{HAZARD ZONES FOR DEBRIS FLOWS, LAHARS, LAVA FLOWS, AND PYROCLASTIC FLOWS FROM MOUNT RAINIER}

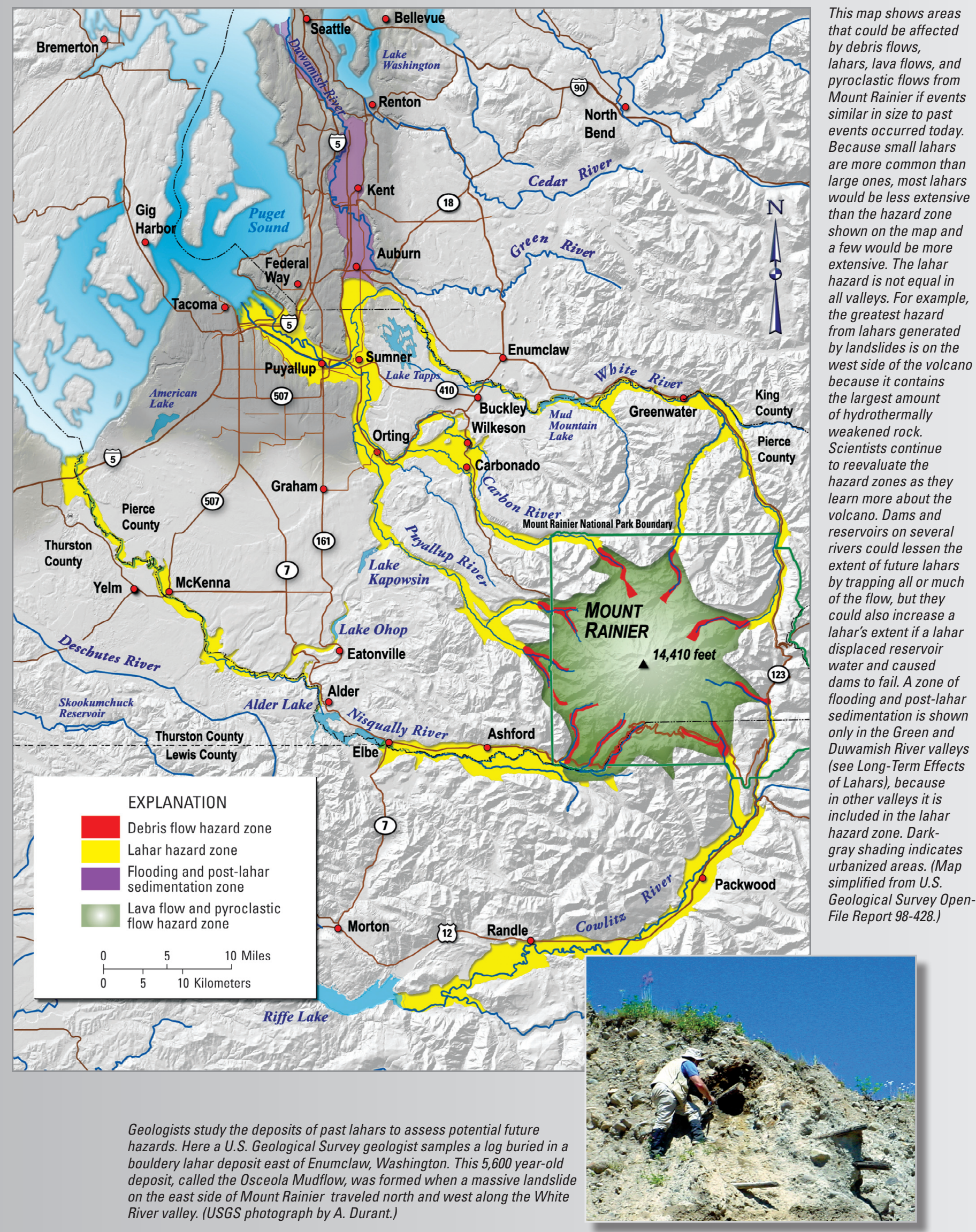


on the flanks of Mount Rainier. Such debris flows behave like lahars, but are typically of such small size that they seldom travel beyond the base of the volcano and only affect vulnerable areas within the boundaries of Mount Rainier National Park. Summer and autumn are the seasons during which debris flows are most common-times when glaciers are producing large amounts of meltwater and intense rains can fall on littlevegetated, snow-free areas with abundant loose debris. Because debris flows pose risks to park visitors and infrastructure, especially trails, roads, and bridges, Mount Rainier National Park educates staff and visitors about hazards from debris flows and how to avoid them by moving off valley floors.

\section{Past Lahars Provide Clues About Future Hazards}

Lahars leave behind thick layers of boulders, mud, and logs on valley floors. Geologists use this and other evidence to assess future hazard potential and to map zones in river valleys heading on Mount Rainier that could be inundated by future lahars. Not all valleys would necessarily be affected during a given eruption or large landslide, nor would all lahars in a valley be large enough to extend to hazard-zone boundaries. Lahar hazard zones mapped by the USGS are being used to guide the development of hazard-area regulations in comprehensive land-use plans by counties and cities that lie at the foot of Mount Rainier.

\section{Lahar Warning System Reduces Risk}

Because there is higher level of risk from lahars generated by landslides on the west flank of Mount Rainier, the USGS, Pierce County Department of Emergency Management, and Washington State Emergency Management Division have established a lahar warning system. A detection component consists of arrays of monitors that record the ground vibrations of a lahar. Computerized evaluation of data assesses the presence of a flowing lahar and issues an automatic alert to emergency-management agencies. Emergency managers can then initiate appropriate response measures. City, county, and State agencies design and maintain notification procedures, evacuation routes, and public-education programs.

If a large lahar were generated in the upper Puyallup River valley without the precursors that typically herald volcanic unrest and eruption, it could arrive at

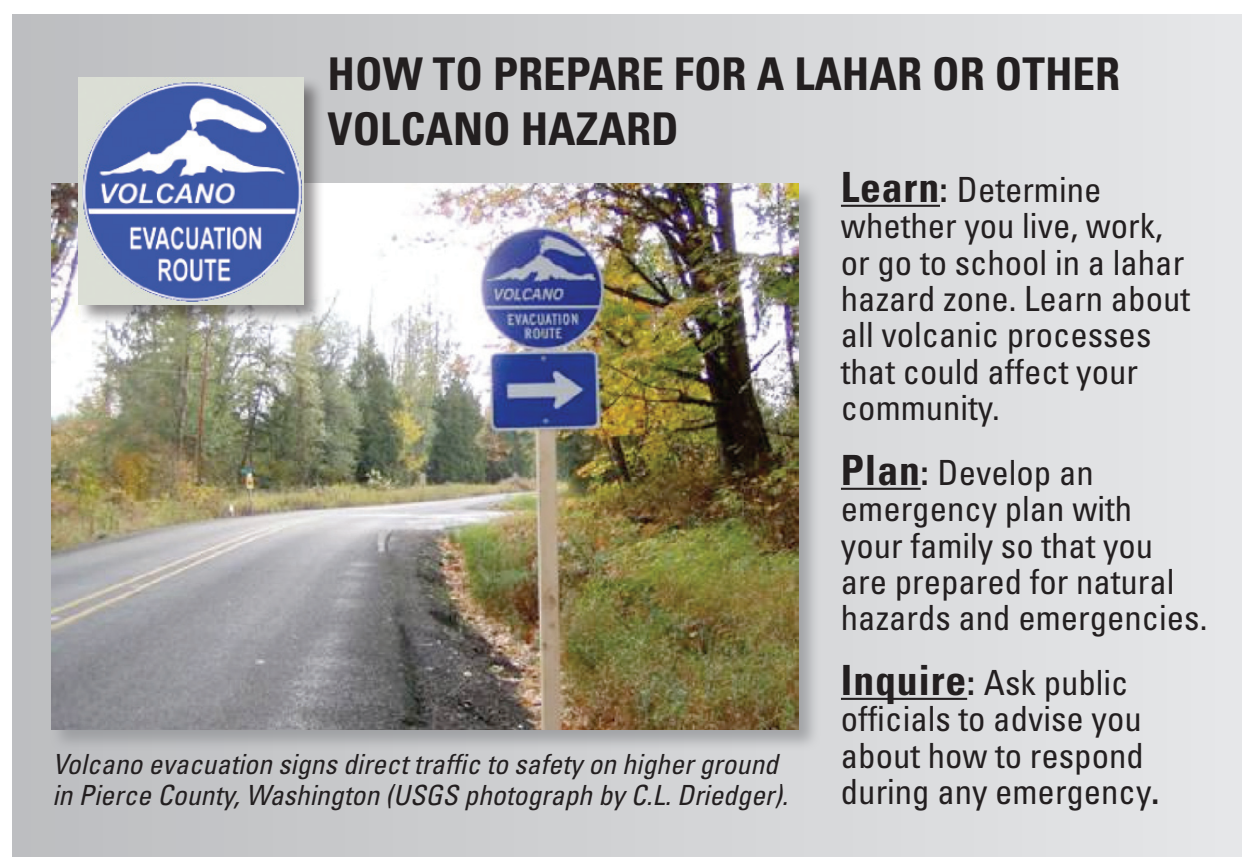

the City of Orting as little as 40 minutes after the initial warning is sounded. Time could be short, and successful mitigation will depend on effective notification of people at risk, public understanding of the hazard, and prompt response by citizens. This system for automatic detection and notification of a lahar reduces - but does not eliminate-risk in the lahar pathways.

\section{Monitoring and Emergency Planning Are Ongoing}

The USGS, in cooperation with the Pacific Northwest Seismic Network at the University of Washington, continuously monitors Mount Rainier and assesses potential hazards stemming from volcanic activity. Volcanoes often show signs of unrest, such as increased seismicity (earthquakes) and emission of volcanic gases and swelling of the volcano, days to months in advance of an eruption. When unrest is detected, scientists will notify emergency-management officials and increase monitoring efforts.

The Mount Rainier Volcanic Hazards Response Plan, which was created by cooperating local, county, State, and Federal agencies, is on the Web at http://www.co.pierce.wa.us/pc/Abtus/ ourorg/dem/EMDiv/Mt\%20Rainier\%20 VHRP.htm. The plan describes the responsibilities of agencies and how they will communicate with each other and the public during a volcanic crisis.

\section{What to Do if Threatened by a Lahar or Debris Flow}

Know the signs of debris flows and lahars. Experience from around the world shows that moving to high ground off the valley floor is the only way to ensure safety during a lahar. When hiking in valleys on the slopes of Mount Rainier during late summer or during intense rainfall, be alert for the signs of an approaching debris flow-ground shaking and roaring sound-and move up the valley wall to higher ground. The same is true for lahars, but, because they affect much larger areas, people need to move out of threatened areas before lahars get close. Lahars are almost always preceded by volcanic unrest, so in most instances there will be time to warn people when there is an increased risk. Obtain a NOAA weather radio to receive alerts about possible lahars, as well as other natural hazards (for further information on the Web go to http://www. weather.gov/nwr.).

Carolyn L. Driedger and William E. Scott

Edited by James W. Hendley II

Graphic design by Jeanne DiLeo and Lisa Faust

For more information contact U.S. Geological Survey David A. Johnston Cascades Volcano Observatory 1300 SE Cardinal Court, Building 10, Suite 100 Vancouver, WA 98683 (360) 993-8900 or

http://vulcan.wr.usgs.gov http://www.pnsn.org/RAINIER/welcome.html

This Fact Sheet supersedes Mount Rainier-Living with Perilous Beauty ((Fact Sheet 065-97) and Mount RainierLearning to Live with Volcanic Risk (Fact Sheet 034-02).

See also Volcano Hazards from Mount Rainier, Washington (U.S. Geological Survey Open-File Report 98-428).

This Fact Sheet and any updates to it are available online at http://pubs.usgs.gov/fs/2008/3062/ 